Supporting Information

\title{
Highly Ordered Pt-Based Nanoparticles Directed by Self-Assembly of Block-Copolymer for Oxygen Reduction Reaction
}

\author{
Zhida Wang, $*, 1,2$ Yilang Mai, ${ }^{1,2,3}$ Yi Yang ${ }^{1,2,3}$ Lisha Shen, ${ }^{1,2}$ Changfeng Yan*,1,2,3 \\ ${ }^{1}$ Hydrogen Production and Utilization Lab, CAS Key Laboratory of Renewable Energy, Guangzhou Institute of \\ Energy Conversion, Chinese Academy of Sciences, Guangzhou, China, 510640. \\ ${ }^{2}$ Guangdong Key Laboratory of New and Renewable Energy Research and Development, Guangzhou, China, \\ 510640 \\ ${ }^{3}$ University of Chinese Academy of Sciences, Beijing, China, 100039. \\ Corresponding author: Changfeng Yan (yancf@ms.giec.ac.cn); Zhida Wang (wangzd@ms.giec.ac.cn)
}




\section{Supporting Figures}

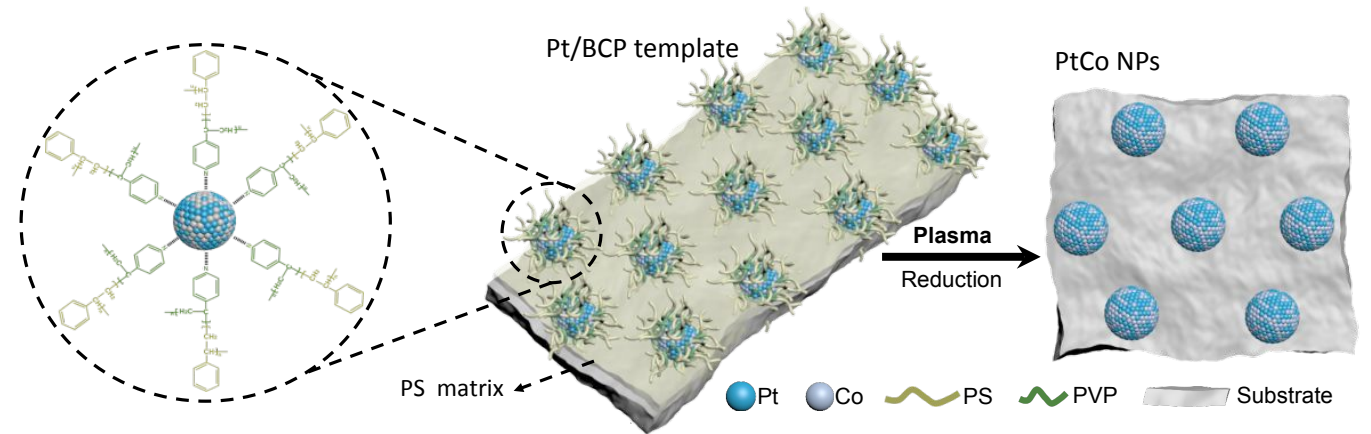

Figure S1. Proposed schematic illustration of the preparation for ordered PtCo NPs.
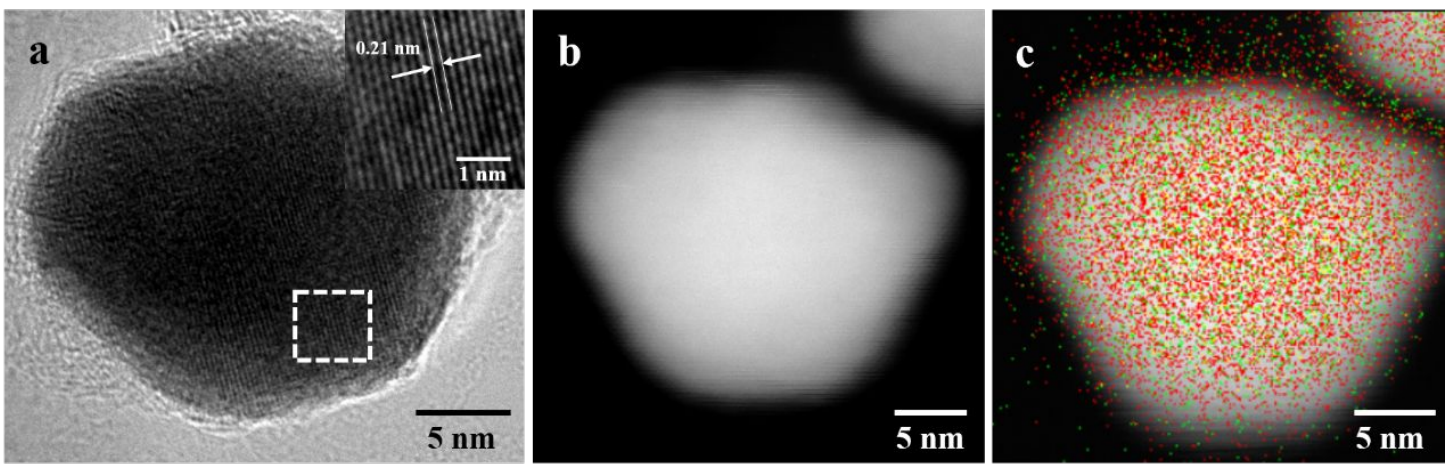

Figure S2. (a) HR-TEM image of PtCo NP. The inset is the inter-fringe distance measured from the boxed area. (b) STEM image the PtCo NP. (c) EDS mapping image of Pt (red) and Co (green).
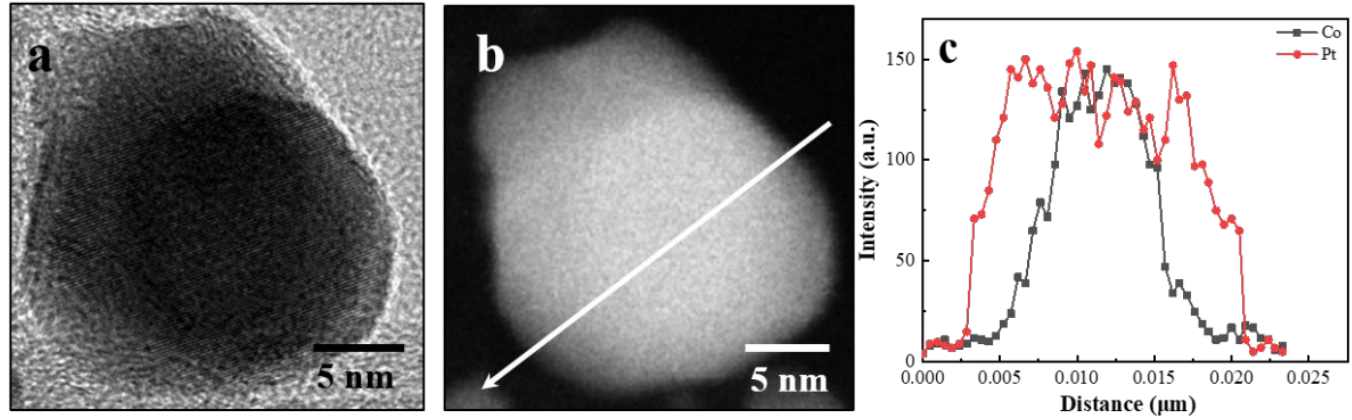

Figure S3. (a) HR-TEM image of a PtCo core-shell NP. (b) and (c) EDS line-scan of the element distribution. 

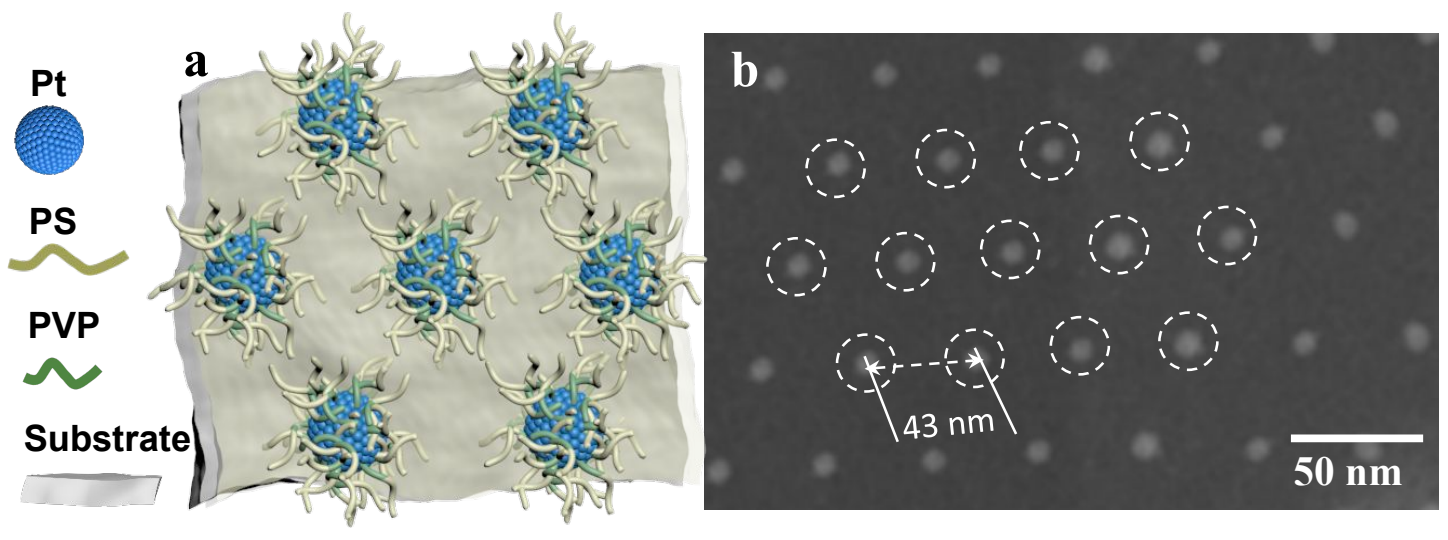

Figure S4. (a) Self-assembled film template of Pt/BCP solution. (b) SEM image of the Pt NP arrays from the $\mathrm{Pt} / \mathrm{BCP}$ solution with a Pt precursor content of $1 \mathrm{mg} / \mathrm{mL}$. The average particle size decreases to $16.5 \mathrm{~nm}$, whereas the center-to-center spacing remains constant as $\sim 43 \mathrm{~nm}$.
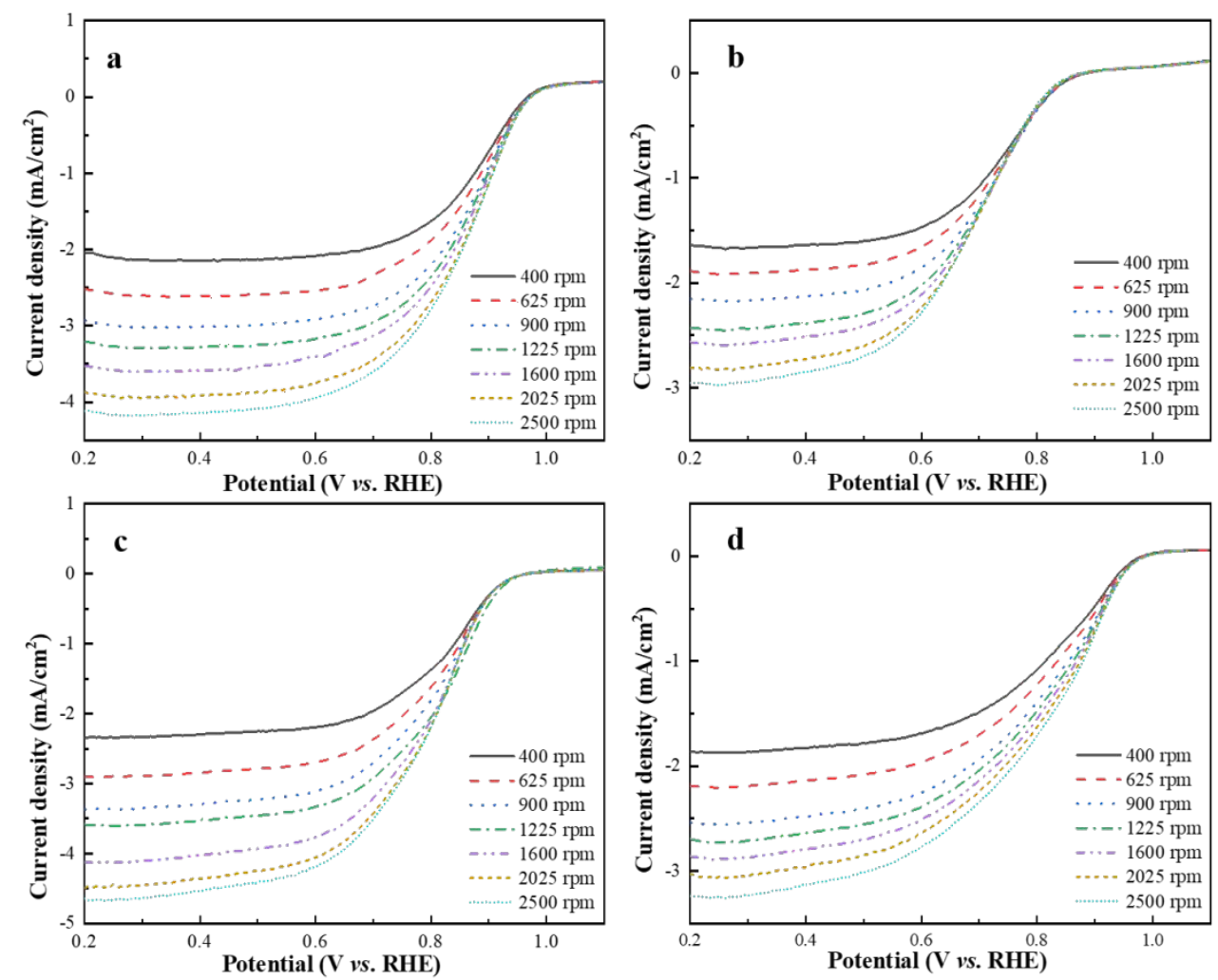

Figure S5. LSV curves of the Pt-based NP arrays and JM 40 at different rotating rates. (a)

PtCo@Pt, (b) PtCo, (c) Pt, (d) JM 40. 

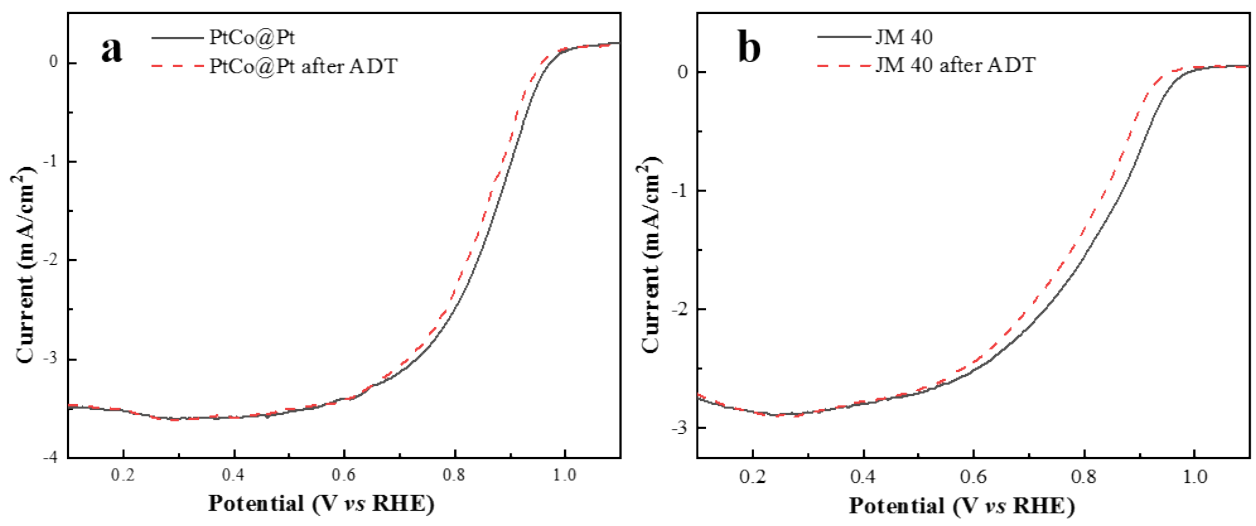

Figure S6. Electrochemical stability tests of (a) the PtCo@Pt NPs and (b) the commercial JM 40 $\mathrm{Pt} / \mathrm{C}$ catalyst.

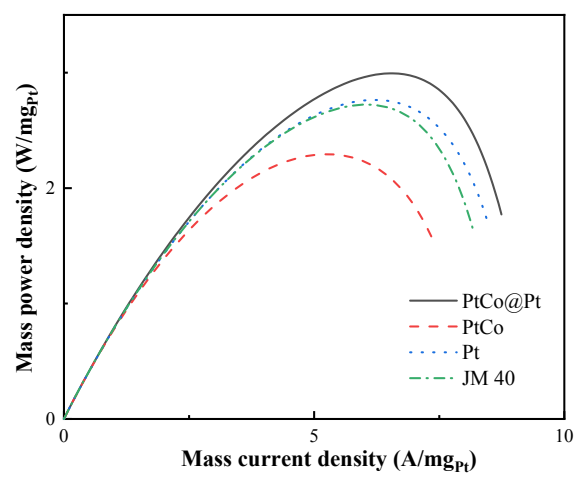

Figure S7. Mass power density (vs. total Pt loading) curves of the Pt-based NPs and JM 40. 

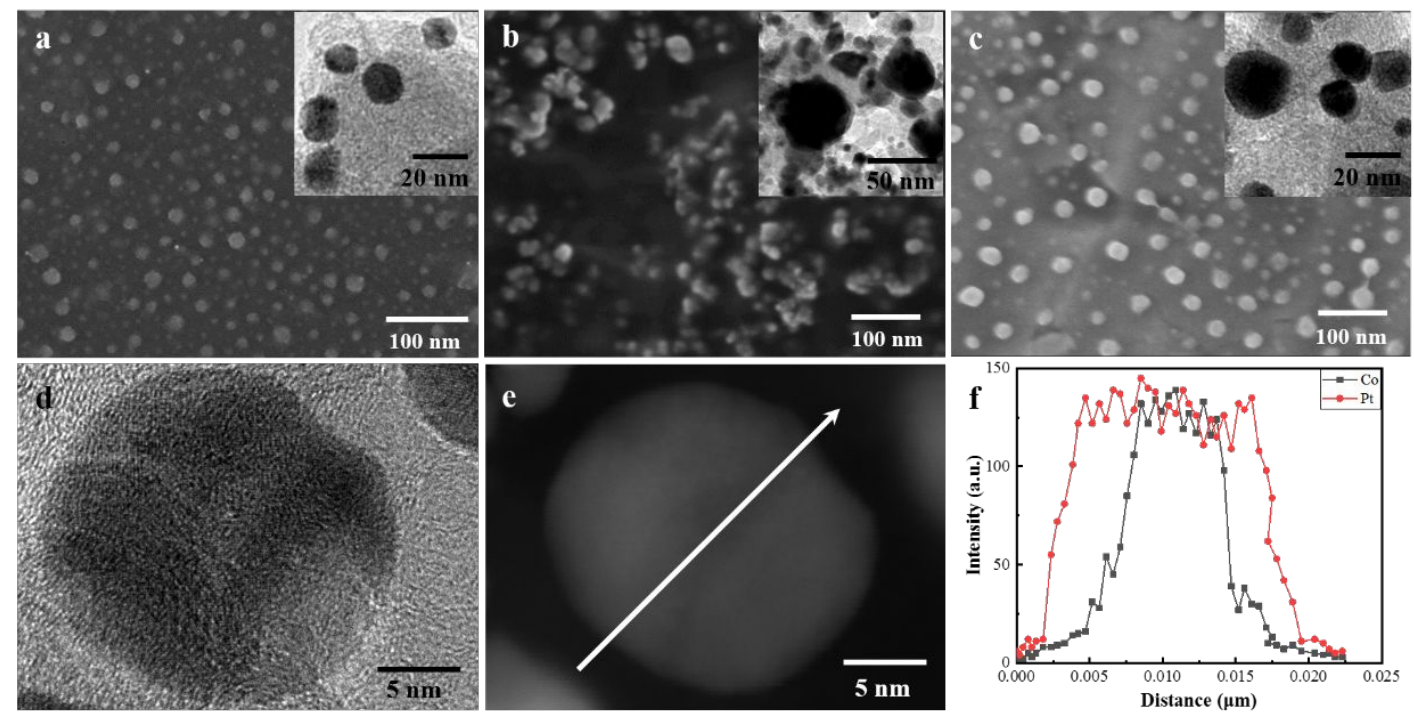

Figure S8. SEM and inserted TEM images of the (a) Pt, (b) PtCo, and (c) PtCo@Pt NPs after durability tests. (d) HR-TEM image of a single aged PtCo@Pt NP. (e) and (f) EDS line-scan.
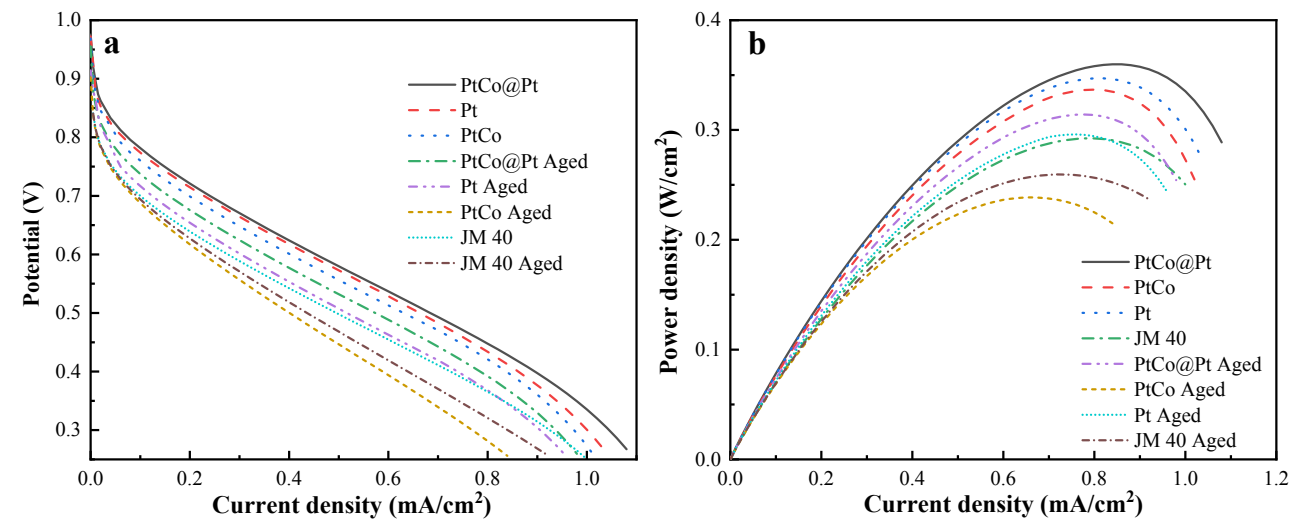

Figure S9. I-V polarization (a) and power density (b) curves at low Pt loading. 


\section{Supporting Tables}

Table S1. Comparison of recently reported PtCo-based materials on ORR electrocatalysts with MEA performance.

\begin{tabular}{ccccccc}
\hline Catalyst & $\begin{array}{c}\text { Pressure } \\
(\mathrm{MPA})\end{array}$ & $\begin{array}{c}\text { Feeding } \\
\text { condition }\end{array}$ & $\begin{array}{c}\text { Pt loading } \\
\text { cathode/anode } \\
\left(\mathrm{mg} / \mathrm{cm}^{2}\right)\end{array}$ & $\begin{array}{c}\text { Current } \\
\text { density at } \\
0.7 \mathrm{~V}\left(\mathrm{~A} / \mathrm{cm}^{2}\right)\end{array}$ & $\begin{array}{c}\text { Peak power } \\
\text { density } \\
\left(\mathrm{W} / \mathrm{cm}^{2}\right)\end{array}$ & Refs \\
\hline $\mathrm{PtCo} @ \mathrm{Pt}$ & 1.6 & $\mathrm{H}_{2}-\mathrm{O}_{2}$ & $0.15 / 0.2$ & 0.86 & 1.05 & This work \\
$\mathrm{PtCo} @ \mathrm{Pt}$ & 1 & $\mathrm{H}_{2}$-air & $0.2 / 0.2$ & 0.41 & 0.84 & Ref 6 \\
$\mathrm{Co} @ \mathrm{Pt}$ & 0.6 & $\mathrm{H}_{2}$-air & $0.36 / 0.2$ & 0.4 & 0.47 & Ref 15 \\
$\mathrm{Pt} 3 \mathrm{Co}$ & 1.5 & $\mathrm{H}_{2}$-air & $0.1 / 0.25$ & 0.72 & 0.65 & Ref 16 \\
$\mathrm{Pd} @ \mathrm{Pt} t_{3} \mathrm{Co}$ & 1 & $\mathrm{H}_{2}-\mathrm{O}_{2}$ & $0.25 / 0.25$ & 0.82 & 0.86 & Ref 38 \\
$\mathrm{PtCo} @ \mathrm{PtAu}$ & 1.6 & $\mathrm{H}_{2}-\mathrm{O}_{2}$ & $0.2 / 0.2$ & 0.91 & 1.12 & Ref 42 \\
\hline
\end{tabular}

Table S2. Activity and durability in PEMFC test for the Pt, PtCo and PtCo@Pt NPs.

\begin{tabular}{ccccc}
\hline NPs & PtCo@Pt & PtCo & Pt & JM 40 \\
\hline Initial current density at $0.7 \mathrm{~V}\left(\mathrm{~A} / \mathrm{cm}^{2}\right)$ & 0.86 & 0.67 & 0.78 & 0.78 \\
Current density at $0.7 \mathrm{~V}$ after 10000 cycles $\left(\mathrm{A} / \mathrm{cm}^{2}\right)$ & 0.70 & 0.39 & 0.66 & 0.59 \\
Current density retention $(\%)$ & 81.4 & 58.2 & 83.5 & 74.6 \\
Initial peak power density $\left(\mathrm{W} / \mathrm{cm}^{2}\right)$ & 1.05 & 0.80 & 0.97 & 0.96 \\
Peak power density after 10000 cycles $\left(\mathrm{W} / \mathrm{cm}^{2}\right)$ & 0.87 & 0.50 & 0.79 & 0.71 \\
Peak power density retention $(\%)$ & 82.9 & 62.5 & 81.4 & 74.0 \\
\hline
\end{tabular}




\section{Supporting calculations on transferred electron number $(n)$ and the oxygen} binding energy $\left(E_{O}\right)$.

(1) Calculation details of the transferred electro number $n$ based on the K-L plots.

The electron transfer number were calculated from the slope of the Koutechy-Levich (K-L) plots containing the measured current density of $I^{1}$

$$
\frac{1}{I}=\frac{1}{I_{k}}+\frac{1}{I_{d}}
$$

Here, $I_{k}$ is the kinetic limiting current density. $I_{d}$ represents the diffusion-limiting current density and is as a function of transferred electron number $n$ and the rotating speed $\omega:^{2}$

$$
\frac{1}{I_{d}}=\frac{1}{0.62 n F C_{0} v^{-1 / 6} D_{0}^{2 / 3} \omega^{1 / 2}}
$$

where $F$ is the Faraday constant of $96485 \mathrm{C} / \mathrm{mol} . C_{0}$ and $D_{0}$ are associated to $\mathrm{O}_{2}$, indicating the concentration in the bulk $\left(1.26 \times 10^{-6} \mathrm{~mol} / \mathrm{cm}^{3}\right)$ and the diffusion coefficient $\left(1.7 \times 10^{-5} \mathrm{~cm}^{2} / \mathrm{s}\right)$, respectively. $v$ is related to $\mathrm{HClO}_{4}$ and is the kinematic viscosity $\left(1.009 \times 10^{-2} \mathrm{~cm}^{2} / \mathrm{s}\right)$.

(2) Calculation details of the oxygen binding energy $\left(E_{O}\right)$.

$\left(E_{O}\right)$ was defined as follow: ${ }^{3}$

$$
E_{O}=E_{(\operatorname{Surf}+O)}-E_{(\operatorname{Surf})}-\left(E_{\mathrm{H} 2 \mathrm{O}}-E_{\mathrm{H} 2}\right)(3)
$$

where $E_{\text {(Surf }+ \text { ) })}$ was total adsorption energy and $E_{\text {(Surf) }}$ was adsorption energy without O. $E_{\mathrm{H} 2 \mathrm{O}}$ and $E_{\mathrm{H} 2}$ were the energies of $\mathrm{H}_{2} \mathrm{O}$ and $\mathrm{H}_{2}$, respectively.

\section{References}

(1) Murphin Kumar, P. S.; Ponnusamy, V. K.; Deepthi, K. R.; Kumar, G.; Pugazhendhi, 
A.; Abe, H.; Thiripuranthagan, S.; Pal, U.; Krishnan, S. K. Controlled Synthesis of Pt Nanoparticle Supported Tio2 Nanorods as Efficient and Stable Electrocatalysts for the Oxygen Reduction Reaction. J Mater Chem A 2018, 6, 23435-23444.

(2) Li, Z.; Gao, Q.; Zhang, H.; Tian, W.; Tan, Y.; Qian, W.; Liu, Z. Low Content Pt Nanoparticles Anchored on N-Doped Reduced Graphene Oxide with High and Stable Electrocatalytic Activity for Oxygen Reduction Reaction. Sci Rep 2017, 7, 43352.

(3) Norskov, J. K.; Rossmeisl, J.; Logadottir, A.; Lindqvist, L.; Kitchin, J. R.; Bligaard, T.; Jonsson, H. Origin of the Overpotential for Oxygen Reduction at a Fuel-Cell Cathode. J Phys Chem B 2004, 108, 17886-17892. 